\title{
DISEMINACIÓN DECONSTRUCTURA DE LA IDENTIDAD EN UN FULGOR TAN BREVE, DE JIMÉNEZ LOZANO
}

\author{
Francisco Javier Higuero
}

Wayne State University

Con una radicalidad superior a la exteriorizada en el discurso lírico de Tantas devastaciones (1992b), primera recopilación de poemas del prolífico escritor castellano José Jiménez Lozano, en Un fulgor tan breve (1995b) se pone de manifiesto la función deconstructora de un sujeto reflexionante que utiliza el aspecto diseminador del lenguaje, para subvertir cualquier tipo de identidad fija, inconmovible y, en último término, opresora. Conforme Jacques Derrida (1981) ha señalado, con acierto, en Dissemination, todo texto se encuentra estratificado de tal forma que proyecta un ámbito temático, cuya presunta significación está relacionada con otros escritos y géneros discursivos, diseminando así una marcada fuerza vectorial, inherente al lenguaje ${ }^{1}$. Tal dinamis-

1 Para esclarecer el razonamiento discursivo de las reflexiones críticas deconstruccionistas, estudios tales como Derrida de Christopher Norris (1987) o Jacques Derrida. Texto y deconstrucción de Cristina de Peretti (1989) pueden servir como instrumentos hermenéuticos de imprescindible valor. 
mo, en consecuencia, está relacionado con la intertextualidad concomitante a todo ejercicio de la escritura. En Un fulgor tan breve, no es difícil poder establecer relaciones intertextuales entre los diversos poemas de tal obra o entre los mismos y muchos otros escritos narrativos y ensayísticos de Jiménez Lozano. Dicha praxis crítica, exteriorizada en las páginas que siguen del presente artículo, sirve para evidenciar, en Un fulgor tan breve, las reflexiones de un sujeto poético, consciente de la función discursiva de la escritura, la cual mediante un proceso continuo de diseminación linguística, llega hasta deconstruir su propia identidad. En conformidad con dicha estrategia textual, se precisa advertir, desde un primer momento, que la obra lírica aquí estudiada, aunque sea irreductible a concretizaciones conceptuales o metódicas asfixiantes, no por eso se encuentra exenta ni de un estricto rigor de pensamiento, ni tampoco de una adecuada crítica conceptual ${ }^{2}$.

El sujeto poético de Un fulgor tan breve expresa líricamente su convicción de que lo escrito por él no puede ser encapsulado en un discurso autoritario, o dentro de moldes conceptuales que correspondan a determinados sistemas de significación. Conforme se lee en el texto autobiográfico del diario literario Segundo abecedario (1992) del mismo Jiménez Lozano, todo sistema es totalitario por definición. En consonancia con tal apreciación crítica, el discurso de Un fulgor tan breve no se encuentra clausurado en forma alguna, ni tampoco está asentado sobre primeros principios o causas fundantes. Por el contrario, la escritura de los poemas de esa obra desafía la praxis raciocinante que necesita fundamentos inamovibles o que precisa de un centro discursivo o conceptual, en torno al que gire todo lo que se expone. Por otro lado, y en conformidad con el tipo de escritura deconstructora, en Un fulgor tan breve también se llega a poner en duda la prioridad de presencias sobre ausencias, ejemplarizadas a través de las imágenes del vacío y de la nada ${ }^{3}$. No obstante, tampoco dichas ausencias

2 El acusar a la praxis deconstruccionista de subjetivismo esterelizante, o de atentado contra el valor conceptual que posee el discurso teórico, implica un desconocimiento de la obra de Derrida y de los numerosos estudios que sobre ella se han llevado a cabo. A esto conviene añadir que el tipo de estructura deconstructora, tal y como corresponde a Un fulgor tan breve, a pesar de su carácter radical y subversivo, contiene un inevitable rigor lógico que no deja de apelar con penetrante agudeza.

3 Al enfatizar el valor deconstructor de la ausencia, en Un fulgor tan breve, no se está atentando contra la fidelidad a lo real. Lo expuesto en los poemas de està obra está en consonancia con lo defendido en Real Presences (1989) y Martin Heidegger (1991) de George Steiner. Se puede muy bien estar de acuerdo con la línea raciocinante de estas obras, sin compartir los ataques contra la praxis deconstruccionista lanzados por Steiner. Algo parecido quizá sea aplicable, desde otra perspectiva, a lo expuesto por 
se presentan como algo definitivo, con lo que irremediablemente hay que contar. Quizás aquí radique la diferencia textual más significativa y relevante, entre lo expuesto líricamente en Tantas devastaciones (1992b) y en la obra que se comenta en este artículo. El discurso de la primera recopilación de poemas de Jiménez Lozano se caracterizaba por un notable predominio de isotopías focalizadas en torno a una temática propia de la fugacidad temporal, conducente a un estado existencial de ausencias y vacíos irrevocables ${ }^{4}$. Tal apreciación crítica tal vez pueda ser también correctamente aplicable al comienzo del discurso literario de Un fulgor tan breve. Sin embargo, no debe perderse de vista que en esta obra se detecta una evolución progresiva a favor de un cuestionamiento de tal fugacidad, principalmente de lo dejado atrás como irremediable y definitivamente superado.

Es cierto que, al ponerse énfasis en los primeros poemas de Un fulgor tan breve en los cambios atmosféricos y ambientales, ocasionados por el transcurso de las estaciones, quizás se saque la impresión de que todo se transforma fugazmente. Así sucede, por ejemplo, al leer «Otoño», en donde se percibe la sensación del transcurso breve de la tarde y se contempla la muerte de las hojas de la vid ${ }^{5}$. Algo parecido se puede apreciar en «Las Pléyades», en donde la fugacidad temporal está presentada mediante la utilización del recurso discursivo correspondiente a una pregunta formulada en torno al hecho consumado de la desaparición de las golondrinas, cuando se siembra el trigo. En estos poemas aparece, como en muchos otros escritos de Jiménez Lozano, una profusión de imágenes rurales que no se reducen simplemente a la vid, el trigo o las golondrinas, sino que se extienden también al césped, los árboles, la lluvia, el musgo, y muchas otras representaciones del mundo campesino, conforme se pone de manifiesto en los siguientes versos de «Diciembre»:

David H. Hirsch (1991) en The Deconstruction of Literature. Criticism after Auschwitz. El desenmascarar la tendencia totalitaria de teorías actuales de crítica literaria no conlleva necesariamente implicar a la deconstrucción en tales movimientos que, en modo alguno, son subversivos.

${ }_{4}$ El concepto teórico de isotopía, según lo señalado por A.J. Greimas (1971) en Semántica estructural, desempeña el papel funcional de trazar una conexión entre los diversos elementos recurrentes en el texto.

5 Puesto que el sujeto poético se refiere a su propia percepción de lo que él, tal vez, considere fugacidad, cabe la posibilidad de que pueda estar proyectando su estado de ánimo sobre lo que expresa acerca de la naturaleza o la realidad externa. Conforme José Antonio Marina (1994) ha señalado en Teoría de la inteligencia creadora una de las obras ensayísticas de más valor publicadas en España en los últimos años, percibir es asimilar los estímulos, otorgándoles un significado que no necesariamente está en ellos. En definitiva, es el presunto sujeto de la percepción el que crea significados libres, aunque tal libertad esté siempre limitada. 


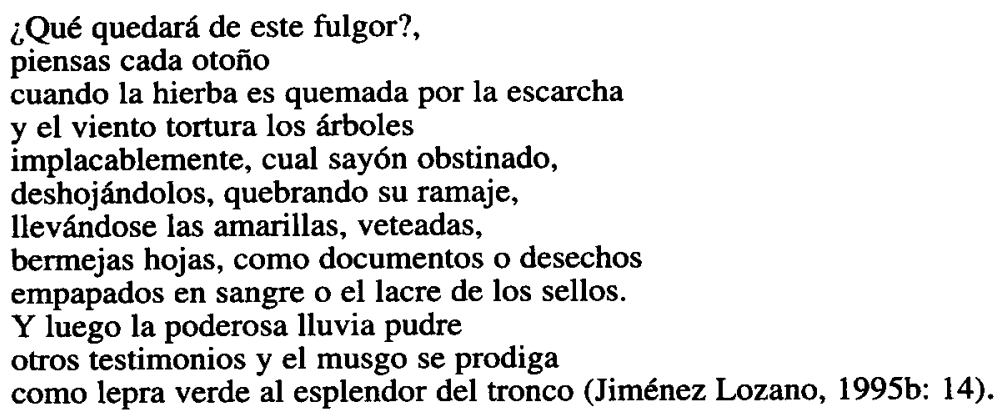

Al final de estos versos citados, parece que se ofrecen indicios textuales que abren posibilidades deconstructoras de la desolación propia de la fugacidad. La referencia explícita al esplendor del tronco, en estas circunstancias, está implicando que no todo se da por perdido. A medida que va avanzando el discurso poético de Un fulgor tan breve se van diseminando matices deconstructores que llegan hasta eliminar la validez semántica de cualquier interpretación de dicha obra que tenga en cuenta solamente la isotopía de la fugacidad. Tal praxis deconstruccionista se pone de relieve, sobre todo, al llegar a los últimos poemas, en los que el énfasis textual parece concentrarse más en presuntas reflexiones históricas, en lugar de percepciones atmosféricas, procedentes de contextos rurales. A este respecto, conviene advertir que en «España antigua» no cabe la consideración de la isotopía de la fugacidad, ya que el discurso lírico de este poema, una y otra vez, evidencia el eterno círculo, donde el ayer, el hoy y el mañana son, sin novedad, lo mismo. Si tal es el caso, nada ha desaparecido fatalmente y todo continúa estando presente de forma deconstructora frente a cualquier tipo de ausencia o fugacidad. El sujeto poético de «España antigua» reflexiona sobre una temática concreta de la historia, evidenciando preocupaciones similares a las que aparecían en el relato breve «La masía» de El santo de mayo (1976) del mismo Jiménez Lozano. En estos dos textos, como en muchos otros de dicho escritor, la realidad de la España ortodoxa se corresponde a un inmovilismo que impide los efectos positivos que la fugacidad de lo caduco lleva consigo. En tales circunstancias, se señala con dolor y preocupación que las novedades son conducidas al confesionario, como si implicaran una traición pecaminosa a la esencia eterna de lo que debería ser España. En Un fulgor tan breve, igual que en el conjunto de la producción literaria de Jiménez Lozano, no se defiende nada que pueda ser equivalente o estar identificado con una presunta esencia de España. Por el contrario, las premisas historiográficas de los textos literarios de este escritor, según se pone de manifiesto en Meditación española sobre la 
libertad religiosa (1966), Los cementerios civiles y la heterodoxia española (1978), Sobre judíos, moriscos y conversos (1982), Guía espiritual de Castilla (1984), Los ojos del icono (1988b), coinciden con la concepción existencial que de la vividura intrahistórica de los españoles aparece en la obra ensayística de Américo Castro ${ }^{6}$.

La eliminación de la propia seguridad, que conlleva la ausencia de toda realidad fija y esencial en la que asirse, se manifiesta, en Un fulgor tan breve, en el estado de ánimo del sujeto reflexionante, caracterizado como repleto de indigencia y anamnético ${ }^{7}$. De una lectura detenida de «Los primeros quince días» se deduce claramente el desconcierto de dicho sujeto al reflexionar sobre realidades tan acuciantes como la muerte y lo implicado en ella, manifestado en jornadas inciertas de horror, cementerio y amargura. Tal es la temática que volverá a repetirse en «El Resucitado de Diego de la Cruz», en donde el discurso lírico se ve obligado a expresar emociones que no pueden olvidar el polvo al que se llega después de peregrinar desde la cuna hasta la muerte. El mismo sujeto poético, aun intentando librarse de tal indigencia, se ve obligado a reconocer que llevaba años rezando a un Cristo, débil, vencido y muerto. En dicho poema, el proceso deconstructor disemina significaciones de indigencia que afectan hasta a la misma victoria de la resurrección. La experiencia del Cristo triunfante se ve subvertida por la realidad inescapable de quien fue crucificado ${ }^{8}$. Este hecho existencial con el que hay que contar no puede aislarse de la problemática radical del mal y del sufrimiento en la que se encuentra inserto el sujeto poético de «Música para un rey agonizante. Sainte-Colombe va a Versalles», quien

6 Al compartir los presupuestos existenciales de Américo Castro, expuestos en De la edad conflictiva (1976), El pensamiento de Cervantes (1972), Teresa la Santa y otros ensayos (1982) y España en su historia. Cristianos, moros y judios (1983), Jiménez Lozano no sólo se opone a toda concepción esencialista fija que impida el cambio y el progreso, sino también muestra su desacuerdo con concepciones historiográficas basadas en datos objetivados y abstraídos de sus correspondientes contornos contextuales, en donde realmente podían tener significación relevante para la vida de seres humanos de carne y hueso.

7 Para una comprensión conceptual de lo connotado por ser anamnético, se precisa tener en cuenta las bases filosófico-teológicas estudiadas, con acierto, precisión y conocimiento de causa, por Reyes Mate en Mística y política (1990) y La razón de los vencidos (1991).

8 Lo expresado líricamente en «El resucitado de Diego de la Cruz» viene a añadirse a múltiples expresiones y modalidades de cruces que se acumulan a lo largo de los escritos de Jiménez Lozano. A este respecto conviene tener presente las cruces de la novela teológica Historia de un otoño (1971) y las de numerosos relatos breves recopilados en El santo de mayo (1976), El grano de maiz rojo (1988a), Los grandes relatos (1991), Objetos perdidos (1993a) y El cogedor de ancianos (1993b). Las connotaciones semánticas de dichas cruces no siempre coinciden y ponen de manifiesto la riqueza polisémica que afecta a gran parte de los textos literarios de Jiménez Lozano. 
llega a reconocer que él mismo ha sido torturado. Desde tal experiencia de dolor abominable se contempla el resplandor musical de la corte del Rey. De la misma forma que la existencia de la cruz deconstruía la presunta victoria de la vida en «El Resucitado de Diego de la Cruz», ahora en «Música para un rey agonizante. Sainte-Colombe va a Versalles» se subvierte y desprecia lo implicado por un contorno existencial subordinado al poder de los grandes. La música, que en tal corte de Versalles tenía una finalidad de ostentosidad complaciente, se ve deconstruida de su presunto valor estético, cuando se tiene en cuenta que fue utilizada para el exterminio de los señores y las monjas del monasterio jansenista de Port-Royal de Champs, conforme ha sido señalado, con acierto, en los ensayos de Jiménez Lozano recopilados en La ronquera de fray Luis y otras inquisiciones (1973). A pesar de la repugnancia que la corte del Rey le inspira al sujeto poético de Un fulgor tan breve, éste decide ir a Versalles solamente cuando se encuentra en condiciones de llevar refrigerio al Rey agonizante. Ya ante el cadáver de este personaje histórico, dicho sujeto cobra conciencia de la vida, al sentirse pobre y desvalido. En tales circunstancias, descansa del mundo y de su ruido, buscando los sonidos exactos para su viola, al mismo tiempo que los anota. Dicha experiencia estética que procede de la situación existencial de indigencia radical se encuentra apoyando las expresiones líricas del sujeto poético, completamente alejado de todo lo que significa complacencia e identificación con un poder que se sirve de todo tipo de estrategias retóricas para sobrevivir, según lo ha advertido en términos teóricos Steven Mailloux (1989) en Rhetorical Power. En conformidad con lo ya indicado, la indigencia radical, sobre la que versan muchos poemas de Un fulgor tan breve, afecta al mismo sujeto poético, que se ve obligado a sentirse inseguro y repleto de dudas que le zarandean. Tal estado de ánimo se expresa mediante una serie de recursos discursivos, procedentes de imágenes limitadoras de la felicidad vital de quien ama este mundo. A tal respecto, no debe dejarse de mencionar la fatalidad de la muerte, a la que se alude en «Las Pléyades» a través del sonido de las campanas, asociado en gran parte de la obra literaria de Jiménez Lozano con connotaciones negativas de frustración existencial. Sin embargo, se precisa reconocer que, aunque es cierto que tal significación hace acto de presencia en los poemas de Un fulgor tan breve, también se alude en ellos a la alegría del nacimiento de un niño, anunciado por las campanas. En otras palabras, es precisamente la dimensión deconstructora de esta obra lírica la que impide la identificación fija de lo connotado por las campanas como algo definitivamente establecido, a pesar de que esto coincide con ras- 
gos textuales sobresalientes en otros momentos literarios de lo producido por Jiménez Lozano. Así se expresa, a este respecto, la equivocidad del lenguaje de las campanas en los versos de «Las Pléyades»:

\author{
La campana retiñe, pero desconfía: \\ ayer pregonaba los amores \\ o que un niño había nacido, y luego \\ tañe por los muertos. No es segura \\ su apuesta, equivocada es su lengua (Jiménez Lozano, 1995b: 12).
}

La polisemia y equivocidad, propia de un discurso deconstructor que disemina significaciones subversivas y abolidoras de toda identidad, afecta no sólo a las imágenes de las campanas, sino a muchas otras, procedentes de un contexto ambiental en contacto directo con el campo y la naturaleza. En «Los árboles azotados por el viento», el sujeto poético, al reflexionar sobre presuntas dudas existenciales, se ve inclinado a pensar en los árboles, que, atormentados por las inclemencias temporales, se zarandean y arrojan hojas a un césped ya azotado por el hielo temprano. Sin embargo, no todo es negativo en esas presuntas imágenes de destrucción, ya que dichas hojas, caracterizadas como lágrimas amarillas o rojas, sirven para esmaltar el oscuro césped. Dicho de otra forma, el efecto estético y visual de las hojas caídas subvierte la destrucción asociada unívocamente con los árboles convertidos en víctimas de las consecuencias arrasadoras del viento. Ante un estado de presunta desolación ambiental y atmosférica, el sujeto poético, aun en medio de un mar de dudas que le hacen cuestionar hasta su propia identidad personal, testimonia una actitud de fe agónica, a través de una oración en la que hay referencias explícitas a los despojos y ruinas con que hay que contar, conforme sucedía en muchos textos narrativos de Jiménez Lozano?. Tales

9 No se necesita estar totalmente familiarizado con el conjunto de la obra literaria de Jiménez Lozano para saber apreciar la dimensión agónica, de procedencia intertextual unamuniana, de personajes agobiados por dudas continuas, frente a las que testimonian su fe. Tal es el caso de lo que les sucedía al Cardenal Noailles y a la Madre Du Mesnil de Historia de un otoño (1971), a Pablo de Olavide en El sambenito (1972) y al científico, a punto de fallecer, del relato breve «La orfandad» de El santo de mayo (1976). Ha sido Thomas Mermall (1983) quien, con su habitual perspicacia crítica, ha sabido relacionar en «José Jiménez Lozano y la renovación del género religioso» esta actitud agónica de personajes creyentes con lo expuesto ensayísticamente por Unamuno en La agonía del cristianismo (1938) y con lo narrado en San Manuel Bueno, mártir (1971). El referirse a las aportaciones de Mermall, al aludir a la relación intertextual que puede establecerse entre la obra de Jiménez Lozano y la de Unamuno, no sólo es costumbre, sino también acto de honradez intelectual. 
dudas contribuyen a deconstruir la identidad de un sujeto poético que, tanto a nivel del discurso lírico como del contenido expresado en Un fulgor tan breve, no duda en desaparecer, haciendo su propia presencia innecesaria. A este respecto conviene advertir que el rasgo textual que parece predominar en «Las estaciones», primer poema de la obra aquí estudiada, es el ascetismo deconstructor de tal sujeto que llega a abolir su papel exclusivo de emisor para convertirse él mismo en receptor de lo expresado. Este poema pone en cuestión seria la identificación distintiva del sujeto poético con la voz hablante que se oye continuamente en $U n$ fulgor tan breve. En algunas ocasiones el predominio de tal sujeto desaparece intencionadamente cuando su individualidad específica se disuelve en una colectividad, convirtiéndose en un hombre cualquiera, e interesándose, de manera directa, no por lo que es, sino por lo que de él dirán después de su muerte, conforme se evidencia en «Preguntas». No obstante, conviene hacer notar que la conversión del sujeto poético individual en alguien carente de señas de identidad en modo alguno consiste en la caída irremediable en el ser inauténtico, criticado por pensadores existencialistas desde Søren Kierkegaard, en The Concept of Anxiety (1980), The Concept of Dread (1957), Either/Or (1959), Fear and Tembling (1968) y For Self-Examination and Judge for Yourselves! (1944), a Martin Heidegger en El ser y el tiempo (1951). La diferencia entre la deconstrucción de la identidad en el sujeto poético de Un fulgor tan breve y la inautenticidad del ser convertido en masa, al que se refieren los existencialistas, radica en que en los escritos de dichos pensadores tal caída en la despersonalización se produce irremediablemente como refugio o máscara frente a las cargas y exigencias del encuentro del ser humano consigo mismo, mientras que en la obra poética aquí estudiada el cuestionamiento de dicho sujeto se realiza conscientemente a través de una serie de interrogaciones que, con radicalidad nunca saciada, ponen en duda cualquier tipo de decisión fija, identificadora e inamovible, conforme se evidencia en los siguientes versos de «Preguntas»:

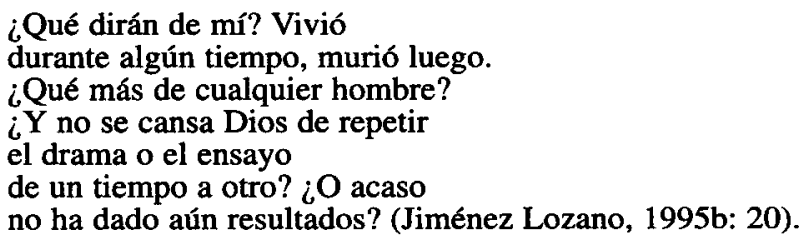

En conformidad con lo que expresan estos versos, el sujeto poético, deconstructor de su propia identidad, tal y como es percibido por los 
otros, no se formula preguntas movido por un afán de huida inauténtica o de refugio que le sirva de protección frente a la angustia existencial, provocada por la amenaza de la nada. Por el contrario, las preguntas de dicho sujeto poético tienen como finalidad un cuestionamiento radical del ser personal y de los papeles que presuntamente ha sido obligado a desempeñar. Conforme José Luis L. Aranguren ha expuesto en obras ensayísticas tales como Sobre imagen, identidad y heterodoxia (1981) y Moral de la vida cotidiana, personal y religiosa (1987), la función que adquieren dichos papeles está relacionada con el establecimiento de la presunta identidad ${ }^{10}$. Ahora bien, ya que los papeles de cada cual dependen, en gran parte, de lo impuesto por los demás, a la hora de cuestionar la propia identidad habrá que referirse a lo que los otros han forjado en uno mismo. Precisamente, tal es el razonamiento que se encuentra detrás de las preguntas formuladas, con persistencia, en Un fulgor tan breve. Por otro lado, no debe perderse de vista que la yuxtaposición simultánea de interrogantes, en dicha obra, sirve también para deconstruir un discurso lineal, encaminado a un final feliz que pudiera servir de satisfacción definitiva a todas las ansiedades y dudas. Conforme sucedía en Relación topográfica (1993) del mismo Jiménez Lozano, aquí también el recurso discursivo de una superposición continua de planos deconstruye todo orden jerarquizante que tenga como consecuencia la implantación de la identidad irrevocable. Los niveles de preguntas e interrogaciones se van yuxtaponiendo indefinidamente, de tal forma que el final de ese proceso ni se vislumbra, ni existe. En consecuencia, las posibles respuestas se diseminan, sin cesar, esparciendo significaciones inestables que precisan de nuevas preguntas nunca satisfechas completamente, ni contestadas de modo convincente. La dinámica interna de tales interrogaciones responde al discurso deconstructor de $U n$ fulgor tan breve, el cual al cuestionar la identidad de todo lo existente extiende el ámbito de preguntas hasta afectar a la consistencia personal del propio sujeto poético.

Otro recurso textual con el que se subvierte todo aquello que se considera fijo e inamovible, en la obra aquí estudiada, se produce en la experiencia onírica. El sueño conlleva el deseo y el ansia de una realidad que no sólo no es la existente, sino que tal vez no sea posible tampoco. Sin embargo, lo implicado en dicho nivel subconsciente y que se encuentra incluido en el ámbito de lo imaginario, según expresa

10 Para un esclarecimiento crítico de la obra ensayística de Aranguren, la obra de Enrique Bonete Perales (1989), Aranguren: La ética entre la religión y la política, continúa siendo un instrumento insuperado de consulta. 
Jacques Lacan en Speech and Language in Psychoanalysis (1968) y Los cuatro conceptos fundamentales de psicoanálisis (1977), posee una fuerza deconstructora de todo aquello que se ve como paralizante, $y$, al mismo tiempo, connota rasgos creativos, relacionados con lo que se anhela. En contra de tal ámbito de lo imaginario, obrará siempre lo impuesto con caracteres de inevitabilidad por el orden simbólico que habrá que deconstruir ${ }^{11}$. A este respecto conviene señalar que el sujeto poético de Un fulgor tan breve, al sentirse atrapado en dicho ámbito impuesto por la fuerza de los hechos históricos consumados, no duda en reconocer que prefiere dormir, para soñar una esperanza, consistente en que se hará la paz, allí donde la estirpe de David había triunfado y producido frutos de odio y destrucción ${ }^{12}$. Tal era lo que había sucedido en España, país al que se le caracteriza como pesadilla de muertos. El sujeto poético no puede estar de acuerdo con el pasado sangriento de un pueblo y no ve otra salida que refugiarse en un sueño de esperanza, donde los espectros amenazantes y fatales no aparezcan. A todo esto conviene añadir que el sueño, al menos a nivel de deseo, se hace también extensivo a los causantes de dicha situación desazonadora y radicalmente molesta. De la siguiente forma, en «Cinco lecciones de repaso sobre Historia de España. III. Espectros de España», se aconseja el estado de reposo onírico, frente a la violencia amenazante:

\author{
¿Qué queréis de mí, habitantes de lo oscuro, \\ donde las raíces y la arena húmeda, \\ terrosos ojos, rotas mandíbulas, descoyuntadas manos, \\ vosotros los fusilados en la tapia, el árbol o en la hierba \\ al alba blanca, instante de oro o fuego, \\ rocío misericordioso y el plomo de las balas, \\ qué queréis de mí, visiones espantosas? \\ Yo os conjuro a que os acostéis entre los pinos \\ y descanséis ya para siempre. ... (Jiménez Lozano, 1995b: 73-74).
}

11 Lo connotado por el ámbito simbólico ha sido estudiado tanto por Lacan en las obras citadas, como por Julia Kristeva en Desire in Language: A Semiotic Approach to Literature and Art (1980) y Revolution in Poetic Language (1984). Lo simbólico corresponde al orden de lo impuesto culturalmente, bien sea bajo formas fijas de lenguaje reforzadas por instituciones autoritarias o bajo modalidades de poder opresivo, ante el que aparentemente no queda alternativa alguna, sino la sumisión.

12 Para poder apreciar críticamente la obra de Jiménez Lozano es imprescindible no perder de vista las relevantes relaciones intertextuales que pueden establecerse con pasajes bíblicos. Sin un conocimiento escriturístico adecuado y sin estar familiarizado con la consiguiente reflexión teológica que sobre dicho conocimiento se asienta, resulta extremadamente difícil, y en muchos casos casi imposible, comentar seriamente los escritos de Jiménez Lozano. Ahí parece radicar la razón que explicaría la existencia de sólamente un número muy reducido de críticos que han analizado aspectos concretos de dicha obra. 
En estos versos se plantea en forma de pregunta el desafío aniquilante que el pasado de muerte representa para el sujeto poético. Ahora bien, puesto que es consciente de la función subversiva y deconstructora de la propia identidad que tiene el sueño, se atreve a aconsejar dicho sujeto, a los agentes de la maldad radical, que también reposen, descansando para siempre. Dicho de otra forma, de modo semejante a como el sujeto poético se disuelve en el ámbito onírico e imaginario del sueño, tal solución debería aplicarse a aquellos derramadores de sangre y causantes de muerte. Conforme se puede observar, lo connotado por el lexema sueño se aplica polisémicamente en el citado poema. El sueño del sujeto lírico significa un refugio frente a aquello que se siente incapaz de enfrentar. En «La cuerda y los ratones», afirma este sujeto que él escribe para que sus sueños le liberen de la muerte; para que su Dios se levante de la nada y le salve con su cálida mano en el sepulcro. Por otro lado, para los agentes de la violencia, el sueño significa el reposo, o tal vez mejor el final del imperio de la fuerza. No obstante, en ambos casos sobresale una función deconstructora, ya que el sueño elimina tanto la identidad consciente del presunto sujeto como el papel actancial de violencia sangrienta de los presuntos agentes, causadores de muertes, sufrimientos y dolor. Por consiguiente, en el poema citado, el sueño implica reposo del mundo y de su ruido, conforme sucedía también en «Cuando Sainte-Colombo descansó», en donde se evidencia, frente a la criminalidad sangrienta de la historia, una admiración sincera por la mansedumbre, el silencio y la fragilidad, características de seres anamnéticos, que, aun careciendo de identidad histórica, están desafiando y deconstruyendo el orden establecido, asentado sobre el poder dominador del más fuerte ${ }^{13}$.

Conforme se está observando, en Un fulgor tan breve, la función subversiva y diseminadora de un discurso deconstructor que afecta a todo tipo de identidad se relaciona con la crítica directa, incisiva y radical a la opresión aniquilante. Teniendo en cuenta tal pragmática del texto, se puede apreciar con claridad lo connotado semánticamente en «El carro de heno», en donde a los ostentadores del poder oficial se les quiere evitar el tener que enfrentarse con la visión de lo representado pictóricamente por Hieronymus Bosch. Según el director del museo, el Presidente de la Poderosa Potencia no debía ver el cuadro oscuro de

13 El desafío de los seres anamnéticos, insertos en el ámbito de la intrahistoria, a los poderes históricos, aun siendo una constante ineludible en el conjunto de la producción literaria de Jiménez Lozano, cobra una relevancia sobresaliente en lo narrado teológicamente en El mudejarillo (1992a) y La boda de Ángela (1993d). 
ese pintor. Si tal plan se hubiera llevado a cabo, no habría deconstrucción alguna del ámbito opresor. Sin embargo, el sujeto poético no tiene más remedio que advertir el hecho de que al director no le dio tiempo para bajar el lienzo y el guía que acompañaba a los poderosos tuvo que reconocer que los triunfadores esqueletos que aparecen en el cuadro no son sino los mártires de la libre empresa y el heno vendría a ser el baluarte de la indestructible democracia. Con tal imagen, se elimina toda consistencia definitiva, fija e inconmovible del régimen económico y político que sustenta la presunta identidad de los poderosos visitantes. No se debe olvidar que si el sujeto poético ha deconstruido la identidad de esos personajes, también ha hecho lo mismo con la suya propia. De esta forma ese sujeto no se coloca él mismo en una situación de poder que sustituiría a la de aquellos, cuyo puesto aspiraría a ocupar. En el discurso deconstructor radical no existe límite en el proceso subversivo y la inestabilidad diferenciadora afecta a toda la praxis de la escritura. Conforme ha sido señalado por Barbara Johnson (1988), en The Critical Difference. Essays in the Contemporary Rhetoric of Reading, comentando la obra $S / Z$ de Roland Barthes (1974), es tal diferencia desestabilizadora la que tiene una marcada connotación subversiva respecto a cualquier identidad, posponiendo indefinidamente la posibilidad de obtener un significado fijo, propio de una totalidad integrada en un conjunto inamovible. Para decirlo de otra forma, de hecho es la diferencia la causante de que la totalización de la presunta identidad sea imposible de obtener.

En Un fulgor tan breve, el discurso deconstructor del poder adquiere múltiples connotaciones y se presenta en circunstancias cambiantes. Es dicha filosofía del devenir aquí implicada, la que, en «Heráclito», ha sido aludida intertextualmente para trazar continuos guiños de sospecha frente a cualquier apariencia definitiva. En tales situaciones, se sabe trascender el plano puramente fenoménico y falso de la realidad para adentrarse en el terreno del silencio y de lo invisible, donde se encuentra el amor ${ }^{14}$. Desde otra perspectiva, en ese poema, lo mismo que en «Ciropedia» y en muchos otros de la obra aquí estudiada, se

14 De la misma forma que podría hacerse todo un estudio deconstructor del poder en el conjunto de la producción literaria de Jiménez Lozano, también es posible elaborar un análisis crítico de los textos de este escritor en función de la apariencia enmascaradora que está amenazando la realidad numénica de lo acontecido. Sin embargo, aquí no se está implicando la defensa de una aproximación hermenéutica basada en la oposición binaria apariencia-realidad. En los escritos de Jiménez Lozano hay elementos textuales más que suficientes que deconstruirían todo tipo de estructura jerarquizante de dominación, fundamentada en cualquier oposición binaria. 
señala una y otra vez que, a pesar de lo brillante y atractivo de las apariencias poderosas, éstas, de hecho, se miden y reposan, se calculan, valoran y levantan en el entramado del dolor y de la muerte, conforme ya se había expuesto ensayísticamente en el artículo autobiográfico de Jiménez Lozano «Desde mi Port-Royal» ${ }^{15}$. El sujeto poético de Un fulgor tan breve sabe muy bien que la púrpura del triunfo se gradúa con las heridas de aquellos que han sido aplastados. Así se expresa esta convicción existencial en el citado poema «Ciropedia»:

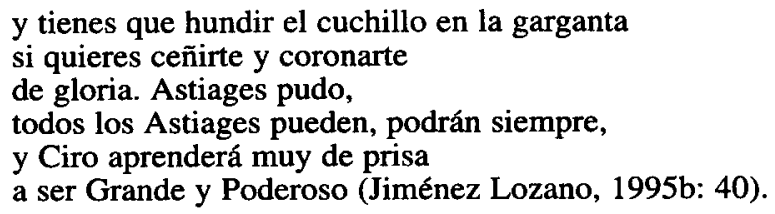

La alusión a personajes históricos, en estos versos, no es accidental e irrelevante. Por el contrario, es en el ámbito opresor de la historia, en el que habitan y con el que creen identificarse Astiages y Ciro, donde, en realidad, se lleva a cabo la victoria de los poderosos, ante la que los seres anamnéticos parecen sentirse víctimas impotentes para modificar el curso de los hechos consumados. Sin embargo, dicho triunfo histórico es deconstruido desde la intrahistoria, convertida en morada existencial de los anamnéticos. A este respecto, conviene señalar que en «Golpe de Estado en Bolivia» se alude subversivamente al tránsito y fugacidad del poder histórico, que, en último término, acaba en la muerte, la sangre y la nada, mientras que un ser anamnético, caracterizado como un anciano, permanecía en su pobreza inalterable, con su corona de hambre y el cetro de su amargura. Es importante referirse a este contraste entre los ámbitos histórico e intrahistórico, no para reforzar el aspecto dominador implicado en una oposición binaria, sino para deconstruir tal recurso textual, aludiendo al hecho verificable de que el sufrimiento afecta a ambos niveles discursivos y no está asentado sólo en uno de ellos, convertido en víctima dualista del otro.

A modo de resumen de todo lo que antecede, podría afirmarse que, en los poemas de Un fulgor tan breve, el sujeto lírico, al criticar

15 El título y gran parte del contenido temático de «Desde mi Port-Royal» (1983) está en correspondencia intertextual directa con la experiencia teológica y literaria del jansenismo, novelada en amplios discursos narrativos que se extienden desde Historia de un otoño (1971) hasta Teorema de Pitágoras (1995a) de Jiménez Lozano. 
subversivamente cualquier contexto de poder, se involucra en un proceso deconstructor de toda identidad, incluida la suya propia. Los rasgos inestables que quedan de este sujeto se diseminan a lo largo del texto escrito de dicha obra literaria. Entre tales rasgos, hay que mencionar una inseguridad constante y radical, lo mismo que un estado preocupante de indigencia, inserto en una problemática de sufrimiento inevitable. Sin embargo, conviene no olvidar que son las propias dudas de ese sujeto las que impiden que cualquiera de los rasgos diseminados linguiísticamente, en los poemas respectivos, puedan convertirse en algo fijo y estable, productor de una nueva identidad. Si el sujeto lírico de Un fulgor tan breve se disuelve en el anonimato fáctico de la colectividad o se refugia en el sueño, es precisamente para impedir que de él quede algún residuo fundante de cualquier tipo de realidad, no sometida todavía al proceso deconstructor propuesto. Por último, se precisa hacer notar que la fluidez discursiva del discurso lírico de los poemas aquí estudiados en modo alguno elimina el rigor estético y la finura espiritual de un texto polisémico, abierto sin cesar a multiplicidad de lecturas crecientemente enriquecedoras.

\section{Referencias bibliográficas}

ARANGUREN, J.L.L. (1981). Sobre imagen, identidad y heterodoxia. Madrid: Taurus.

- (1987). Moral de la vida cotidiana, personal y religiosa. Madrid: Tecnos. BARTHES, R. (1974). S/Z. New York: Hill and Wang.

Bonete Perales, E. (1989). Aranguren: La ética entre la religión y la política. Madrid: Tecnos.

CAstro, A. (1972). El pensamiento de Cervantes.. Barcelona: Noguer.

- (1974). Cervantes y los casticismos españoles. Madrid: Alianza.

- (1975). La realidad histórica de España. México: Porrúa.

- (1976). De la edad conflictiva. Madrid: Taurus.

- (1982). Teresa la Santa y otros ensayos. Madrid: Alianza.

- (1983). España en su historia. Cristianos, moros y judios. Barcelona: Crítica.

Derrida, J. (1981). Dissemination. London: Athlone Press.

GreImas, A.J. (1971). Semántica estructural. Madrid: Gredos.

HeidegGer, M. (1951). El ser y el tiempo. México: Fondo de Cultura Económica.

HIRSCH, D.H. (1991). The Deconstruction of Literature. Criticism after Auschwitz. Hanover: Brown University Press. 
Jiménez Lozano, J. (1966). Meditación española sobre la libertad religiosa. Barcelona: Destino.

- (1971). Historia de un otoño. Barcelona: Destino.

- (1972). El sambenito. Barcelona: Destino.

- (1973). La ronquera de fray Luis y otras inquisiciones. Barcelona: Destino.

- (1976). El santo de mayo. Barcelona: Destino.

- (1978). Los cementerios civiles y la heterodoxia española. Madrid: Taurus.

- (1982). Sobre judios, moriscos y conversos. Valladolid: Ámbito.

- (1983). «Desde mi Port-Royal.» Anthropos 25, 79.

- (1984). Guía espiritual de Castilla. Valladolid: Ámbito.

- (1988a). El grano de maíz rojo. Barcelona: Anthropos.

- (1988b). Los ojos del icono. Valladolid: Caja de Ahorros de Salamanca.

- (1991). Los grandes relatos. Barcelona: Anthropos.

- (1992a). El mudejarillo. Barcelona: Anthropos.

- (1992b). Tantas devastaciones. Valladolid: Fundación Jorge Guillén.

- (1992c). Segundo abecedario. Barcelona: Anthropos.

- (1993a). Objetos perdidos. Valladolid: Ámbito.

- (1993b). El cogedor de ancianos. Barcelona: Anthropos.

- (1993c). Relación topográfica. Barcelona: Anthropos.

- (1993d). La boda de Ángela. Barcelona: Seix Barral.

- (1995a). Teorema de Pitágoras. Barcelona: Seix Barral.

- (1995b). Un fulgor tan breve. Madrid: Hiperión.

Johnson, B. (1988). The Critical Difference. Essays in the Contemporary Rhetoric of Reading. Baltimore: The Johns Hopkins University Press.

KIERKEGAARD, S. (1944). For Self-Examination and Judge for Yourselves! Princeton: Princeton University Press.

- (1957).The Concept of Dread. Princeton: Princeton University Press.

- (1959). Either/Or. New York: Doubleday.

- (1968). Fear and Trembling. Princeton: Princeton University Press.

- (1980). The Concept of Anxiety. Princeton: Princeton University Press.

KristeVA, J. (1980). Desire in Language: A Semiotic Approach to Literature and Art. New York: Columbia University Press.

- (1984). Revolution in Poetic Language. New York: Columbia University Press.

LACAN, J. (1968). Speech and Language in Psychoanalysis: The Language of the Self. Baltimore: Johns Hopkins University Press.

- (1977). Los cuatro conceptos fundamentales del psicoanálisis. Barcelona: Barral Editores.

MaIlloux, S. (1989). Rhetorical Power. Ithaca: Cornell University Press.

MATE, R. (1990). Mística y política. Estella: Editorial Verbo Divino.

- (1991). La razón de los vencidos. Barcelona: Anthropos.

Mermall, T. (1983). «José Jiménez Lozano y la renovación del género religioso.» Anthropos 25, 66-69. 
MARINA, J. A. (1994). Teoría de la inteligencia creadora. Barcelona: Anagrama. NORRIS, C. (1987). Derrida. Cambridge: Harvard University Press.

PeretTI, C. (1989). Jacques Derrida. Texto y deconstrucción. Barcelona: Anthropos.

SteINER, G. (1989). Real Presences. Chicago: The University of Chicago Press.

- (1991). Martin Heidegger. Chicago: The University of Chicago Press. UnAmuno, M. (1938). La agonía del cristianismo. Buenos Aires: Losada.

- (1971). San Manuel Bueno, mártir. Madrid: Alianza. 